\title{
Science educational game: Increase procedural knowledge?
}

\author{
Dimas Wahyu Indrata ${ }^{1,}{ }^{*}$, Arum Adita ${ }^{2}$, Muvida Nofiana ${ }^{3}$ \\ Biology Education Department, Faculty of Teacher Training and Education, Universitas Muhammadiyah \\ Purwokerto, Indonesia \\ ${ }^{1}$ dimaswahyuindrata@gmail.com *, ${ }^{2}$ arumadita@ump.ac.id, ${ }^{3}$ mufidanofiana@ump.ac.id \\ * Corresponding author
}

Check for updates

\begin{tabular}{l}
\hline ARTICLE INFO \\
\hline Article history \\
Selected paper from The $3^{\text {rd }}$ \\
Symposium on Biology Education \\
(Symbion), Yogyakarta-Indonesia, \\
August 31, 2019. Peer-reviewed \\
by Symbion Committee and \\
Editorial Board of Jurnal \\
Bioedukatika
\end{tabular}

Received December 30, 2019

Revised May 5, 2020

Accepted August 4, 2020

Keyword:

Learning media

Science education game

Procedural knowledge

\begin{abstract}
Developing educational game as an alternative of science learning media in SMP Negeri 1 Sokaraja. The purpose of this study was to determine the level of feasibility of science education games and to determine the effect of games on students' procedural knowledge. The designed educational game contained testing procedure of food substances on the materials of digestive system. The research was taken place in SMP Negeri 1 Sokaraja. The sample in this study were 33 eight grade students. The method used was ADDIE Analysis; Design Development and Implementation, and Evaluation. The instruments used were questionnaires, pre-test questions, and post-test questions. Quantitative analysis techniques were used for data analysis. The results of the game feasibility were determined through validation activities by material experts, media experts, teachers and students. The feasibility of the game by material experts indicated a percentage of $90 \%$ with a good category, media experts proved a percentage of $72.85 \%$ with adequate categories, science teachers showed a percentage of $95.68 \%$ with a good category and the eligibility by students confirmed a percentage of $79.02 \%$ with a good category. N-Gain Test Value of 0.179 meant that the effect of games as a science learning media was in low category.
\end{abstract}

This is an open access article under the CC-BY-SA license.

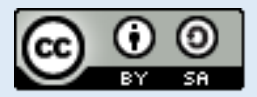

\section{Introduction}

The development of information and communication technology has a significant impact on various fields of life, one of them is education. The need for information and communication technology for education is difficult to avoid. Information and communication technology is one solution to improve the quality of education process (Budiana, Sjafirah, \& Bakti, 2015). Nuryadin, Kamil, \& Firmansyah (2018) stated that quality of education was born from a good learning process, and created a good learning process required components in the learning process. One of these components is learning media (Falahudin, 2014).

Learning media developed with computer have various types. One of them is multimedia learning. Kurniawati and Nita (2018) stated that learning multimedia was a medium that combined text, art, sound, images, animation, and video that could be used interactively to help learning activities. Permana S, Darmawiguna, and Kesiman (2014) stated that interactive learning multimedia was one type of 
learning media that has been widely used by teachers in the learning process. The use of interactive multimedia learning will attract more interest in learning if it is based on game media. However, game media has not been widely applied in science learning (Cheng, Chen, Chu, \& Chen, 2015). According to Pratama and Haryanto (2018), 90\% of digital games circulating in the market contain elements and acts of violence, so some of these games can actually provide a negative perspective on games.

Games can be meaningful if it is in accordance with learning needs as a learning medium. Adita, Kusuma, and Risnani (2018) stated that the need and perception of Mathematics and Natural Sciences educational games for junior high school students in the Banyumas Regency showed a high percentage. The highest percentage was the indicator of understanding the benefits of educational games by students (81.25\%) and teachers (85.49\%), indicating a need in the school regarding educational games, especially MIPA educational games.

Learning using educational games has several advantages, including increasing students' understanding of the learning material provided (Khenissi, Essalmi, \& Jemni, 2015). Educational games can help students understand the concept (Rizal \& Hernawati, 2017). The element of repetition in educational games, especially when students have not reached the maximum score, will help students improve their understanding of concepts, especially material on science learning (Adita et al., 2018). Video games can stimulate mental structures than traditional learning. Mental structures obtained directly from student experiences will last longer (Corredor, Gaydos, \& Squire, 2014). Another advantage is that educational games can build student motivation because it changes learning to be more interactive (Johnson et al., 2012).

Increased understanding of science learning is might be increasing conceptual or procedural knowledge. According to Anderson and Krathwohl (2001), knowledge dimensions include factual knowledge, conceptual knowledge, procedural knowledge, and metacognitive knowledge. Increasing procedural knowledge in biology learning is fundamental. The procedural knowledge dimension is defined as knowing how to do something such as knowledge of skills, algorithms, techniques, and methods that are collectively known as procedures or can be described as a series of steps (Anderson \& Krathwohl, 2001).

Students' procedural knowledge can improve conceptual understanding and vice versa. According to Kollöffel and de Jong (2013), conceptual understanding will improve procedural skills. Learners trying to explain the conceptual basis of procedures can build greater awareness of which concepts contribute to solving problems and are more likely to operationalize them in the future.

The characteristics of science learning emphasize knowledge of all processes that occur in nature. Yuliati (2013) stated that science learning began with a phenomenon around students. Juanengsih, Purnamasari, and Muslim (2017) stated that science subjects could connect theory with practice, which constructs students' knowledge of the environment. The problem is that students have not been able to connect what is learned with how this knowledge will be used or utilized, especially on abstract material that cannot be observed directly except with the help of the media. Through an emphasis on procedural knowledge, students are expected to be able to connect theory and practice.

Preliminary research at SMP Negeri 1 Sokaraja showed that the procedural knowledge of students in science subjects was low. It was because learning still used lecture method; the media used was oneway and less interactive; and the inefficient use of infrastructure supported students' understanding of the process, for example, practicum was not implementing on some science materials.

The human digestive system material is one of the materials that require media to help students understanding. Khasanah and Samawi (2018) stated that teachers had difficulty conveying material about the human digestive system as a whole because teachers have limited media. So far, the material of the human digestive system was conveyed using images and torso media. The image media was still not effectively used in learning the digestive system material because the image media tends to be monotonous so that it made children bored. Apart from that, the model statue's media made it easier for students to understand the digestive organs were 
often damaged, and the price was relatively high.

One of the efforts to improve students' procedural knowledge is use educational games as learning media. Junike, Yusrizal, and Halim (2016) stated that educators should use other supporting media to support students' procedural knowledge in the learning process. The use of educational games can be a bridge between the real world and the virtual to help students learn more effectively (Li \& Tsai, 2013).

The dimensions of procedural knowledge have not been developed enough through games. Educational games can support students' procedural knowledge because it has simulation content that can train students to perform process skills. This is supported by Srisawasdi and Panjaburee (2019) opinion that game development with scientific content has not been developed much. According to Mulyani, Liliasari, Wiji, Hana, and Nursa'adah (2016), ICT-based games or media can improve scientific skills and improve cognitive abilities (Khoiriah, Jalmo, \& Abdurrahman, 2016). Therefore, the research objective was to determine the feasibility level of educational games and determine the effect of games on procedural knowledge.

\section{Method}

The development model in this study used ADDIE, which consists of the Analysis, Design, Development and Implementation, and Evaluation stages. The data collection instruments used were questionnaires, pre-test, and post-test questions. The questionnaire compiled was a closed questionnaire using a modified Likert rating scale with four ratings, Strongly Agree, Agree, Disagree, and Strongly Disagree. The questionnaire was used to measure the game's feasibility or the quality of the game, while the pre-test and post-test questions were used to measure procedural knowledge. The sampling technique was purposive sampling. Data collection techniques in this study were by filling out questionnaires and working on test questions. The data collected included game quality assessment data by material experts, media experts, science teachers, students, and procedural ability data before and after using educational games.
The data analysis technique in this research was descriptive quantitative. Quantitative data analysis was done by calculating the percentage used to determine the game's feasibility based on the number of scoring for each answer obtained from each questionnaire. The percentage obtained was then compared with Table 1 to obtain the criteria.

Table 1. Percentage of category division (Dopo \& Ismaniati, 2016)

\begin{tabular}{ll}
\hline \multicolumn{1}{c}{ Category } & Percentage (\%) \\
\hline Good & $76-100$ \\
Good Enough & $56-75$ \\
Not Good Enough & $40-55$ \\
Very Bad & Less than 40 \\
\hline
\end{tabular}

The N-Gain test was carried out to determine the effect of games on procedural knowledge based on the number of scoring for each answer obtained from the percentage obtained then compared with Table 2 to obtain criteria.

Table 2. Category of acquisition N-Gain score (Hake, 1999)

\begin{tabular}{ll}
\hline \multicolumn{1}{c}{ N-Gain scores } & \multicolumn{1}{c}{ Category } \\
\hline $\mathrm{g}>0.7$ & High \\
$0.3<\mathrm{g} \leq 0.7$ & Medium \\
$\mathrm{g} \leq 0.3$ & Low \\
\hline
\end{tabular}

\section{Results and Discussion}

This research was conducted to develop the "Digestive" game as a science educational game media on the digestive system material. The process of developing a science educational game used the ADDIE development model. Based on the ADDIE development model, the research stages could be explained as follows.

\section{Analysis Stage}

The initial stage in development research was the analysis stage. The analysis was carried out through previous research literature and interviews with teachers and students of class VIII at SMP Negeri 1 Sokaraja. The initial analysis was about the needs of educational games and curriculum needs. Adita et al., (2018) stated that there was a need for MIPA educational games in the Banyumas district. In addition, the perceptions of teachers and students about Mathematics and Natural Sciences educational games for junior high school students in Banyumas Regency showed a good 
percentage, the highest percentage on the indicator of understanding the benefits of educational games by students was $81.25 \%$ and by teachers was $85.49 \%$. This aspect of understanding relates to the need for digital game development.

The school used in the study was SMP Negeri 1 Sokaraja, Banyumas Regency. SMP Negeri 1 Sokaraja is one of the schools with quite complete facilities and infrastructures such as computer and science laboratories, but has not been fully utilized. A preliminary study of science teachers showed that science learning in schools never utilized computer laboratories, only using Power point-based media, and did not carry out practicum learning on some science material on digestive system material. If it is presented attractively, for example, with learning media in the form of games, science material can improve student understanding. Teachers at SMP Negeri 1 Sokaraja strongly supported the use of educational games to support students' understanding of science material. It showed that there was a need in the school regarding educational games, especially MIPA educational games.

The curriculum used in SMP Negeri 1 Sokaraja was the 2013 curriculum. Data on

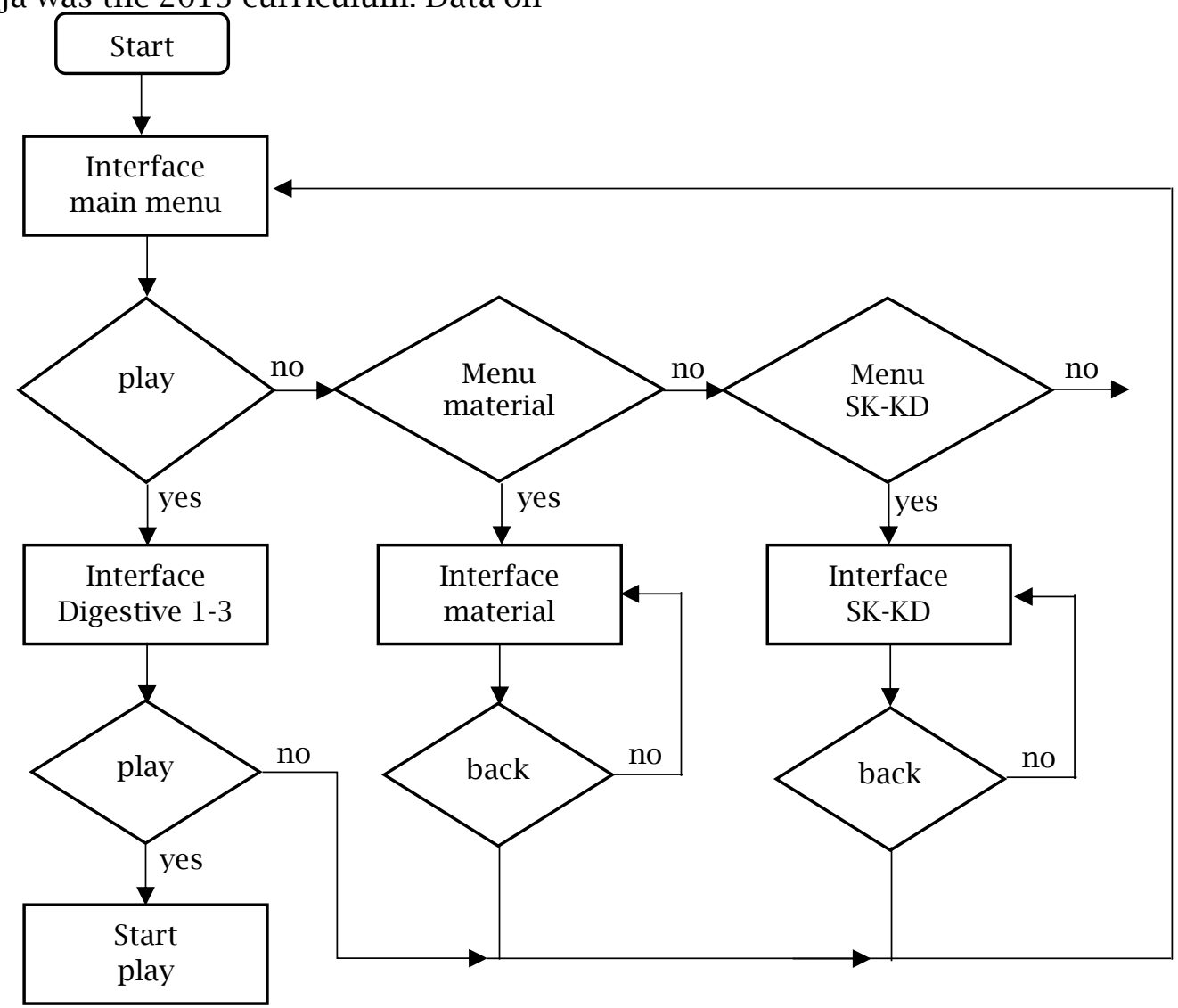

Figure 1. Navigation design the syllabus of the human digestive system material in grade VIII showed that the curriculum demand on these materials includes four competencies, they are competence in spiritual attitudes, social attitudes, knowledge, and skills.

\section{Design Stage}

The design stage began with data design, navigation design, and user interface design. The data design was done by collecting material from the competence of the digestive system.

The knowledge emphasized on the digestive system's material was procedural knowledge, including skills, rules, actions, and goals. Each aspect was formulated in the form of learning indicators, such as the skills aspect having indicators determining the tools needed to test food and determining the ingredients needed to test the food. The data obtained were then converted into puzzle games, simulations, and quizzes sorted into individual levels.

Navigation design aimed as a way of moving between one scene to another scene. This navigation design was made as a flowchart. The result of the navigation design was presented in Figure 1. 
The design of the user interface aimed to make information technology easy to use. The user interface consists of several designs created in scene per scene, they are the intro menu, main menu, level menu, game design, score design, material menu design. Here was an example of a user interface design could be seen in Figure 2 and 3.

Background class

\begin{tabular}{|c|}
\hline play \\
\hline materi \\
\hline
\end{tabular}

Logo Game

Figure 2. Main menu design

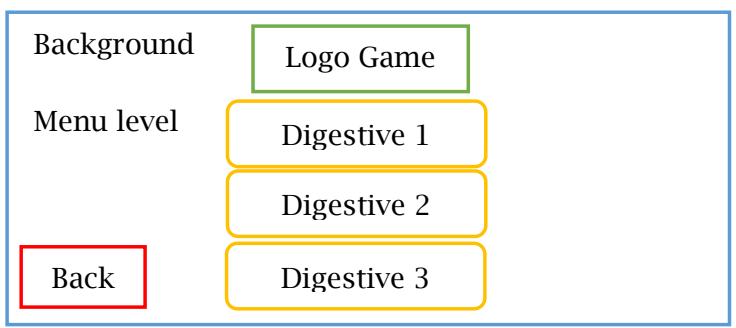

Figure 3. Level menu design

\section{Development stage}

Game development was made according to the game design in the previous stage. The development stage includes user interface development, programming development, and expert testing.

Table 3. User Interface Development

Aspect
Main Menu Display
Design

User interface development was the next stage in the implementation of the user interface design stage. At this stage, the researcher developed all aspects of the design stage to produce an appropriate user interface. User interface development in the science education game (Digestive) was presented in Table 3.

The development of science educational game programming aimed to be used by all computer devices. The application used to develop games was Unity 5.3.4f1. This application combined visual graphics with a programming code called Unity script $(\mathrm{C} \#)$ to get the desired animation. The development of science educational game programming reviewed by learning material expert and media expert. The material expert's assessment of the science educational game includes content and purpose aspects, also instructional aspects. The assessment result by material experts showed that the percentage was $90 \%$ in the good category. The result of the science educational game's feasibility test by the material expert was presented in Figure 4.

Comment and suggestion from material expert related to science educational games was the material revision to improve science educational game media, such as additional material and writing structure of sentences.

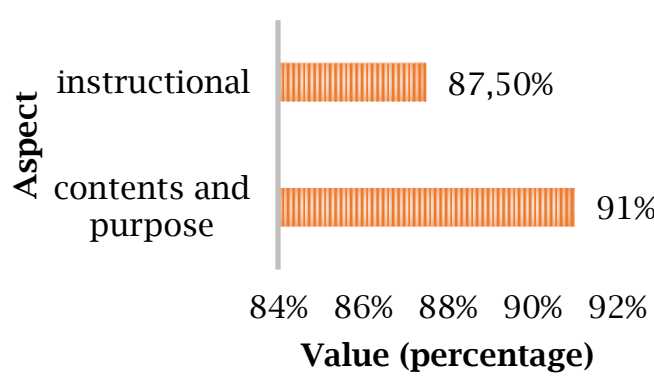

Figure 4. Feasibility test for science educational games by material expert

The completeness of the material presented in the game will help student learning activities more efficiently. It is in accordance with the opinion that the use of media make the learning process more efficient and can help students absorb the subject matter more deeply and completely (Falahudin, 2014). The results of the stage 1 game revision based on comments and suggestions from material experts were presented in Table 4. 
Table 4. The results of the stage 1 game revision based on comments and suggestions from the material expert

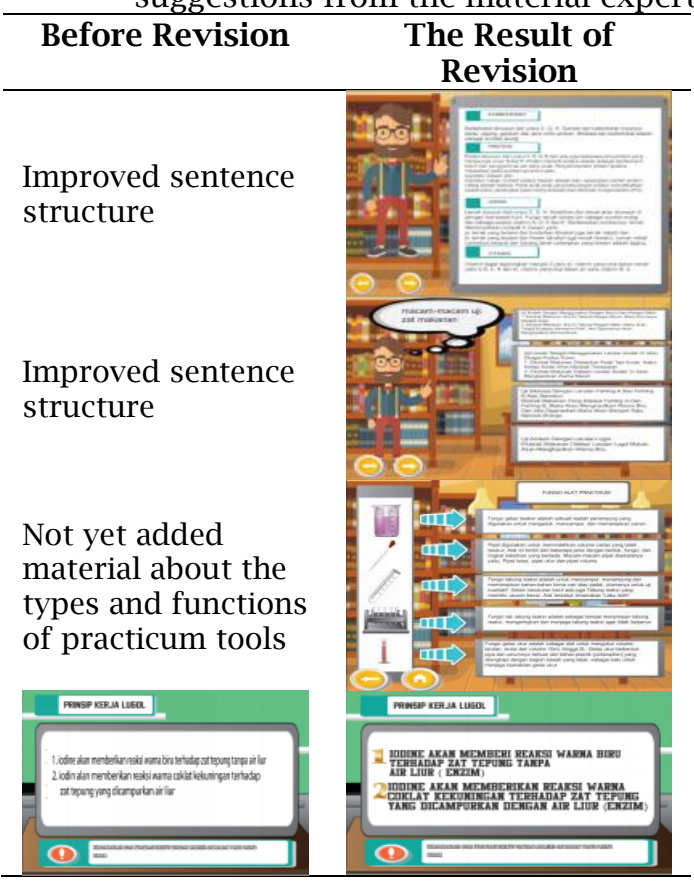

The feasibility test of media expert on science educational games include display aspects and aspects of use and operation. The results of the assessment by media expert showed a percentage of $72.85 \%$ in the adequate category. The result of the feasibility test of the media expert was presented in Figure 5.

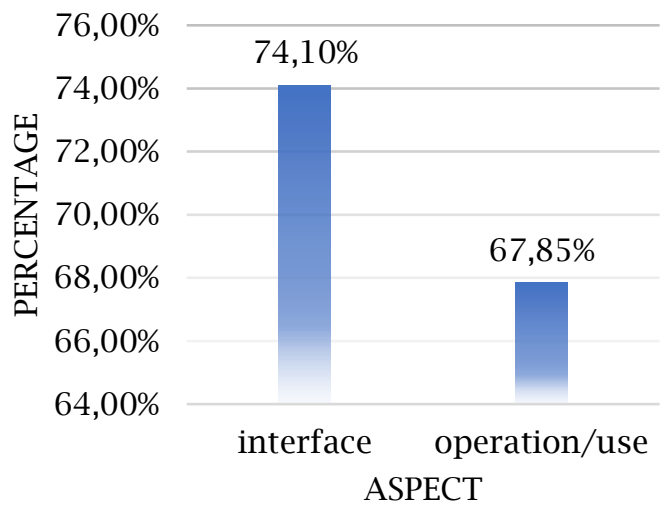

Figure 5. Feasibility test for science educational games by media expert

Comment and suggestion from media expert regarding science educational games was an improvement in graphic quality. The graphic quality was one of the attractions for students to play games to stimulate student fantasies. Educational games were expected to stimulate student fantasies to make it easier for students to understand abstract material in the game. It was in accordance with the opinion of Plass, Homer, and Kinzer (2015) on several important characteristics in games such as learning objectives, narrative, aesthetics, game mechanics, and music. The stage 1 game revision results based on comments and suggestions from media experts were presented in Table 5.

Table 5. Results of stage 1 game revisions based on comments and suggestions from media expert

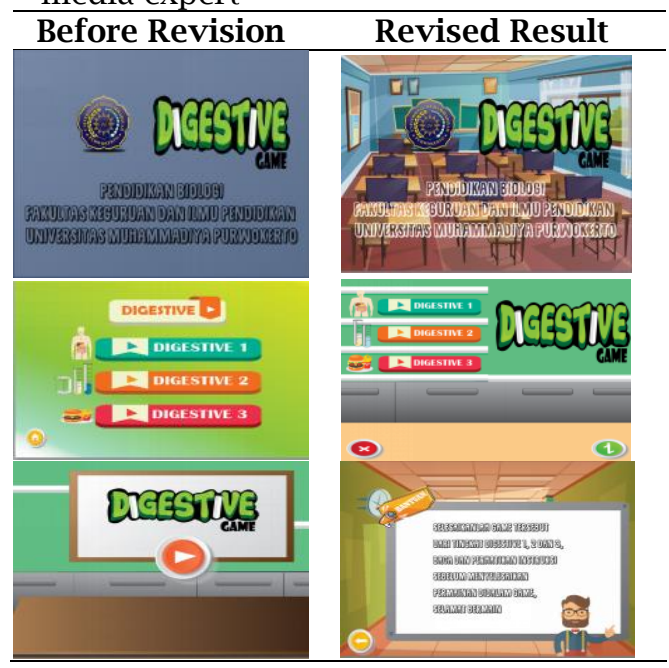

The teacher's assessment results showed that the science educational games that had been developed met the needs of science educational games in schools and could improve students' understanding. It was in accordance with the opinion of Khenissi et al. (2015), which stated that learning using educational games could improve students' understanding of the learning material provided. Educational games can be used to improve students' procedural knowledge because the games developed in them contain practicum simulations containing the steps of the food substance test experiment.

Procedural knowledge is knowledge of the steps required to achieve various goals (Khamidah, 2017). Indicators of procedural knowledge in this study include determining the tools and materials needed to test food; determine the objectives/procedures for testing food substances; determine the appropriate test of the food ingredients served, and prove the food substance through the food substance testing procedure.

However, there was a suggestion for improvement from the teacher. It was 
adding an evaluation "level" for the entire digestive system material. The addition of an evaluation "level" was seen as important for assessing student knowledge. It was in accordance with the opinion of Suryani (2017) that evaluation in learning is one of the very important activities carried out to monitor the quality of learning and help the teaching and learning process.

Based on the results of the science teacher assessment, it can be explained that the total percentage obtained was 95.68\%. Based on the predetermined eligibility criteria, this science educational game was in a good category as a science educational game media for junior high schools on the digestive system material. The results of the feasibility test by the teacher can be seen in Figure 6 .

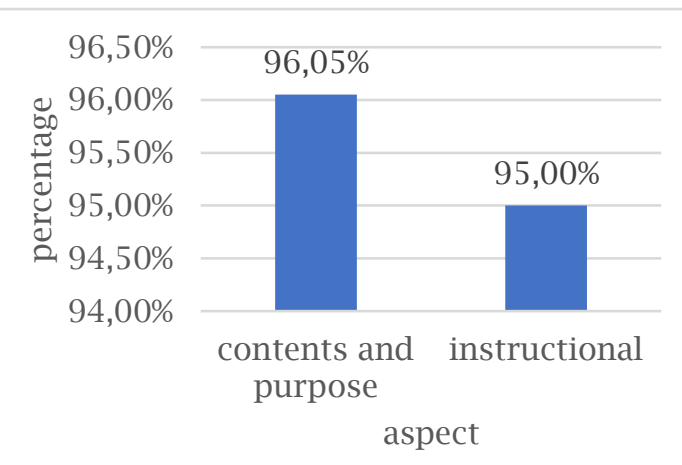

Figure 6. The feasibility test of the science educational game by the teacher

The results of the assessment by students can be explained that the total percentage obtained was $79.02 \%$. Based on the predetermined eligibility criteria, this science educational game was in a good category as an educational game media for learning material on the human digestive system. The results of the feasibility test by the teacher can be seen in Figure 7 .

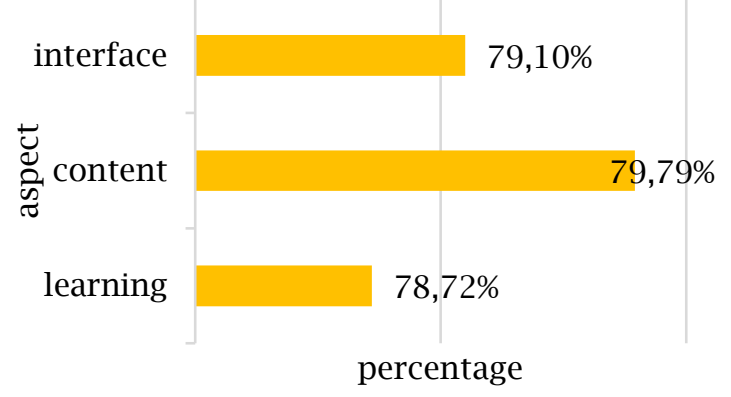

Figure 7 . The student's feasibility test

\section{Implementation stage}

The implementation stage was carried out by testing the science educational game media by students. The game testing activity began with giving pre-test questions, and then a science educational game was tried by students. Students who participated are 33 people according to the number of students in one class. After tried the game, the students worked on the posttest questions. The results of the students' pre-test and post-test scores are presented in Figure 8.

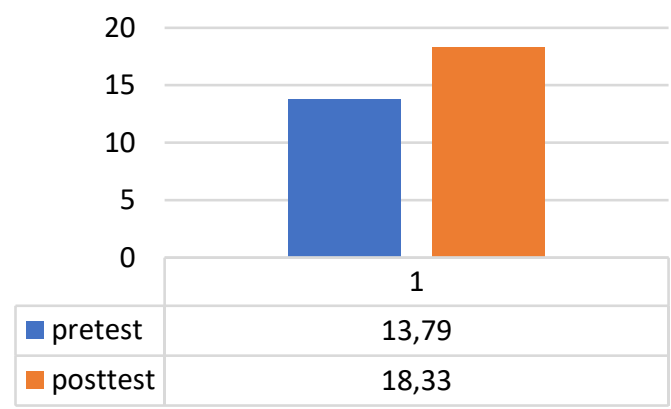

Figure 8. Average students' pre-test and post-test

Based on Figure 8, it could be seen that the average post-test score was higher than the pre-test score. This showed that there were differences in procedural skills before and after learning using educational game media. Procedural skills in the research were focused on the ability to test food ingredients. One of the indicators was selecting materials and tools for food testing. The game was designed with a simulation then given a puzzle to select the appropriate materials and tools. The use of media was in accordance with the opinion of Junike et al. (2016) which stated that in the learning process, it was better for educators to use other supporting media to support students' procedural knowledge.

The use of educational game media in learning could facilitate interaction between teacher and students so that learning activities would be more effective and efficient. This was in accordance with the opinion of Arsyad (2016) which stated that learning media could expedite and improve student learning processes and outcomes, and could overcome limitations of senses, space, and time. Educational game media could make learning more interesting and interactive (Muhson, 2010).

The effect of using games on procedural knowledge was seen from the 
gain value which has a low effect. The average N-Gain value was 0.1719 , which indicated the $g$ value $\leq 0.3$. This was due to several factors, one of which was students were not familiar with the use of science educational games in the learning process. According to Juanda, Gunawan, and Mujiburrohman (2012), the number of educational games was limited and rarely used by teachers or parents. Therefore, children more familiar with games that were less useful than educational games.

Evaluation stage

VIII grade students as research subject stated that the science educational games that had been developed were interesting, could improve students' insights and skills. This was according to the opinion of Ariyanto (2017) that educational games had several benefits, one of them was they could train children's skills. Science educational games could be a learning medium that could help students learn and eliminate boredom in learning. Johnson et al. (2012) stated that educational games were able to build student motivation. in addition to avoiding the saturation of learning activities, using educational games would leave a long impression on students' memories.

Suggestions for improvements in the quality of science educational games were game control must be more accessible, more digestive challenge missions, more graphics, and should to develop font sizes and music. These elements were important because they could increase student interest in games, make it easier to use games, and increase students' knowledge through adding game "levels".

\section{Conclusion}

The research conclusion was the validation assessment results by material experts, media experts, teachers, and students showed that the science education game was suitable for use as a learning medium on the digestive system material. It was also known that the digestive games in this study had a low effect on procedural knowledge. Low results could be caused by the limited number of levels, short time in the trial, and students were not familiar with educational games in learning.

Suggestions that could be submitted regarding the research process were as follows: 1) The use of educational games must be accustomed to learning so that students were accustomed and interested in learning with the help of educational games rather than just playing noneducational games. 2) There was a need for further research on the development of science educational games to increase procedural knowledge with a higher version, that is the 3D version or the virtual laboratory version. 3) The low increase in procedural knowledge in this study could be improved by inquiry-based learning in future studies. 4) In addition, the trial in this study were still limited to one class, so that the effectiveness was not known.

\section{References}

Adita, A., Kusuma, A. B., \& Risnani, L. Y. (2018). Analisis kebutuhan game edukasi MIPA. JURNAL BIOEDUKATIKA, 5(2), 86-91. https://doi.org/10.26555/bioeduk atika.v5i2.7374

Anderson, L. W., \& Krathwohl, D. R. (2001). A taxonomy for learning, teaching, and assessing : a revision of Bloom's taxonomy of educational objectives. Retrieved from https://books. google.co.id

Ariyanto, A. (2017). Game edukatif sebagai upaya mengatasi kesulitan belajar bahasa arab kelas rendah. $A L^{-}$ ASASIYYA: Journal Of Basic Education, 1(2), 78-90. https://doi.org/10.24269/ajbe.v1i2 .686

Arsyad, A. (2016). Media pembelajaran (Revisi). Jakarta: Rajawali Pers.

Budiana, H. R., Sjafirah, N. A., \& Bakti, I. (2015). Pemanfaatan teknologi informasi dan komunikasi dalam pembelajaran bagi para guru SMPN 2 Kawali Desa Citeureup Kabupaten Ciamis. Dharmakarya: Jurnal Aplikasi Ipteks Untuk Masyarakat, 4(1), 59-62. Retrieved from http://journal.unpad.ac.id/dharma karya/article/viewFile/9042

Cheng, M.-T., Chen, J.-H., Chu, S.-J., \& Chen, S.-Y. (2015). The use of serious games in science education: a review of selected empirical research from 2002 to 2013. Journal of Computers in Education, 2(3), 353-375. https://doi.org/10. 1007/s40692-015-0039-9 
Corredor, J., Gaydos, M., \& Squire, K. (2014). Seeing change in time: Video games to teach about temporal change in scientific phenomena. Journal of Science Education and Technology, 23(3), 324-343. https://doi.org/10. 1007/s10956-013-9466-4

Dopo, F. B., \& Ismaniati, C. (2016). Persepsi guru tentang digital natives, sumber belajar digital dan motivasi memanfaatkan sumber belajar digital. Jurnal Inovasi Teknologi Pendidikan, 3(1), 13-24. https:// doi.org/10.21831/tp.v3i1.8280

Falahudin, I. (2014). Pemanfaatan media dalam pembelajaran. Jurnal Lingkar Widyaiswara, 1(4), 104117. Retrieved from https:// juliwi.com/published/E0104/Paper 0104_104-117.pdf

Hake, R. R. (1999). Analyzing change/gain scores. Retrieved from https://www.physics.indiana.edu/ $\sim$ sdi/AnalyzingChange-Gain.pdf

Johnson, J., Buckingham Shum, S., Willis, A., Bishop, S., Zamenopoulos, T., Swithenby, S., ... Helbing, D. (2012). The future ICT education accelerator. The European Physical Journal Special Topics, 214(1), 215243. https://doi.org/10.1140/epjst /e2012-01693-0

Juanda, E. A., Gunawan, T., \& Mujiburrohman, D. (2012). Penerapan model pembelajaran berbasis games (Tic Tac Toe) dalam upaya meningkatkan pemahaman konsep pada mata diktat elektronika dasar. Jurnal Pendidikan Teknologi Dan Kejuruan, 21(2), 123-129. Retrieved from https://journal. uny.ac.id/index.php/jptk/article/vi ew/3279

Juanengsih, N., Purnamasari, L., \& Muslim, B. (2017). Pengaruh model pembelajaran berbasis proyek terhadap pengetahuan prosedural siswa pada konsep Eubacteria. Bioedukasi: Jurnal Pendidikan Biologi, 10(2), 23-28. Retrieved from https://jurnal.uns.ac.id/ bioedukasi/article/view/12488

Junike, J., Yusrizal, Y., \& Halim, A. (2016). Pengembangan dan implementasi instrumen tes untuk mengukur pengetahuan prosedural dengan menggunakan pendekatan inkuiri di SMA Negeri 10 Banda Aceh. Jurnal Pendidikan Sains Indonesia (Indonesian Journal of Science Education), 4(1), 52-63. Retrieved from http://www.jurnal.unsyiah.ac. id/JPSI/article/view/6584

Khamidah, L. (2017). Pemahaman konseptual dan pengetahuan prosedural siswa kelas VIII dalam penyelesaian soal matematika pada Pemahaman Konseptual dan Pengetahuan Prosedural Siswa Kelas VIII dalam Penyelesaian Soal Matematika pada materi sistem persamaan linear dua variabel. Prosiding S1 MaNIs (Seminar Nasional Integrasi Matematika Dan Nilai Islami), 611-616. Retrieved from http://conferences.uinmalang.ac.id/index.php/SIMANIS/a rticle/view/297

Khasanah, U., \& Samawi, A. (2018). Pengembangan media apron sistem pencernaan manusia untuk siswa tunarungu. Jurnal ORTOPEDAGOGIA, 4(1), 22-25. https://doi.org/10.17977/um031v 4i12018p022

Khenissi, M. A., Essalmi, F., \& Jemni, M. (2015). Comparison between serious games and learning version of existing games. Procedia - Social and Behavioral Sciences, 191, 487494. https://doi.org/10.1016/j. sbspro.2015.04.380

Khoiriah, K., Jalmo, T., \& Abdurrahman, A. (2016). The effect of multimediabased teaching materials in science toward students' cognitive improvement. Jurnal Pendidikan IPA Indonesia, 5(1), 75-82. Retrieved from https://journal. unnes.ac.id/nju/index.php/jpii/art icle/view/5793

Kollöffel, B., \& de Jong, T. (2013). Conceptual understanding of electrical circuits in secondary vocational engineering education: Combining traditional instruction with inquiry learning in a virtual lab. Journal of Engineering Education, 102(3), 375-393. https://doi.org/10.1002/jee.20022

Kurniawati, I. D., \& Nita, S.-. (2018). Media pembelajaran berbasis multimedia interaktif untuk meningkatkan 
pemahaman konsep mahasiswa. DoubleClick: Journal of Computer and Information Technology, 1(2), 68-75. https://doi.org/10.25273/ doubleclick.v1i2.1540

Li, M.-C., \& Tsai, C.-C. (2013). Game-based learning in science education: A review of relevant research. Journal of Science Education and Technology, 22(6), 877-898. https://doi.org/10.1007/s10956013-9436-x

Muhson, A. (2010). Pengembangan media pembelajaran berbasis teknologi informasi. Jurnal Pendidikan Akuntansi Indonesia, 8(2), 1-10. https://doi.org/10.21831/jpai.v8i2 .949

Mulyani, S., Liliasari, L., Wiji, W., Hana, M. N., \& Nursa'adah, E. (2016). Improving students' generic skill in science through chemistry learning using ict-based media on reaction rate and osmotic pressure material. Jurnal Pendidikan IPA Indonesia, 5(1), 150-156. Retrieved from https://journal.unnes.ac.id/nju/in dex.php/jpii/article/viewFile/5804 $/ 4718$

Nuryadin, E., Kamil, P. M., \& Firmansyah, H. (2018). Pengaruh penerapan media macromedia flash terhadap hasil belajar peserta didik pada materi sistem pencernaan makanan pada manusia di SMPN 2 Manonjaya Tasikmalaya. BIO EDUCATIO: (The Journal of Science and Biology Education), 3(2), 29-36. Retrieved from http://jurnal.unma.ac.id/ index.php/BE/article/view/1105

Permana S, P. T. H., Darmawiguna, I. G. M., \& Kesiman, M. W. A. (2014). JA-KO Balinese pizza: Game edukasi interaktif jaringan komputer. Jurnal Nasional Pendidikan Teknik Informatika (JANAPATI), 3(2), 8087. https://doi.org/10.23887/jana pati.v3i2.9808
Plass, J. L., Homer, B. D., \& Kinzer, C. K. (2015). Foundations of game-based learning. Educational Psychologist, 50(4), 258-283. https://doi.org/10. 1080/00461520.2015.1122533

Pratama, U. N., \& Haryanto, H. (2018). Pengembangan game edukasi berbasis android tentang domain teknologi pendidikan. Jurnal Inovasi Teknologi Pendidikan, 4(2), 167-184. https://doi.org/10.21831 /jitp.v4i2.12827

Rizal, A., \& Hernawati, K. (2017). Pengembangan game edukasi matematika dengan pendekatan guided discovery untuk siswa SMP kelas VIII. Jurnal Pendidikan Matematika-S1, 6(3), 1-8. Retrieved from http://journal.student.uny.ac. id/ojs/index.php/pmath/article/vi ew/6660

Srisawasdi, N., \& Panjaburee, P. (2019). Implementation of gametransformed inquiry-based learning to promote the understanding of and motivation to learn chemistry. Journal of Science Education and Technology, 28(2), 152-164. https://doi.org/10.1007/s10956018-9754-0

Suryani, Y. E. (2017). Pemetaan kualitas empirik soal ujian akhir semester pada mata pelajaran Bahasa Indonesia SMA di Kabupaten Klaten. Jurnal Penelitian Dan Evaluasi Pendidikan, 21(2), 142152. https://doi.org/10.21831/pep .v21i2.10725

Yuliati, L. (2013). Efektivitas bahan ajar IPA terpadu terhadap kemampuan berpikir tingkat tinggi siswa SMP. Jurnal Pendidikan Fisika Indonesia, $9(1), \quad 53-57 . \quad$ Retrieved from https://journal.unnes.ac.id/nju/in dex.php/JPFI/article/view/2580 